\title{
Perubahan Fisiko-Kimiawi dan Mikrobiologis Minuman Tradisional Bali (Loloh) selama Penyimpanan
}

\author{
Physicochemical and Microbiological Changes in Bali Traditional Beverages (Loloh) during Storage \\ I Desak Putu Kartika Pratiwi*, I Ketut Suter, Putu Ari Sandhi Widpradnyadewi, \\ Anak Agung Istri Sri Wiadnyani
}

Program Studi Ilmu dan Teknologi Pangan, Fakultas Teknologi Pertanian, Universitas Udayana, Jl. Kampus Unud Bukit Jimabran, Badung, Bali, 80361 Indonesia

*Email: kartika.pratiwi@unud.ac.id

Tanggal submisi: 21 Desember 2016; Tanggal penerimaan: 15 Februari 2019

\begin{abstract}
ABSTRAK
Loloh is Balinese traditional beverage made from one or a combination of several herbal extracts. The most popular variants of loloh in Bali are loloh tibah and loloh cem-cem, which are continuously produced every day. During distribution, loloh is stored at room temperature. The study was aimed to study the physico-chemical and microbiological characteristics of loloh cem-cem and loloh tibah during storage at room temperature. This study used a purposive random sampling. The samples consisted of 14 loloh sellers in Badung-Denpasar. Type parameters that were observed during a 24 hour-storage at room temperature included $\mathrm{pH}$, total soluble solid, titratable acidity, ascorbic acid, total plate count, total yeast and mold count. During room temperature storage, the level of total plate count, total mold/yeast of loloh cem-cem and loloh tibah changed significantly. The shelf life of Ioloh cem-cem was only 12 hours at room temperature $\left(28-30{ }^{\circ} \mathrm{C}\right)$ with the characteristics of $\mathrm{pH} 2.95$, TSS 5.67 oBrix, vitamin C $19.35 \mathrm{mg} / 100 \mathrm{~g}$, titratable acidity $0.24 \%$, log total plate count $6.48 \mathrm{Cfu} / \mathrm{mL}$, log total $\mathrm{mold} /$ yeast $5.01 \mathrm{Cfu} / \mathrm{mL}$. The shelf life of Loloh tibah was only 12 hours at room temperature $\left(28-30{ }^{\circ} \mathrm{C}\right)$ with the characteristics of pH 3.34, TSS $4.21 \mathrm{oBrix}$, Vitamin C $10.20 \mathrm{mg} / 100 \mathrm{~g}$, titratable acidity $0.13 \%$, log total plate count $6.68 \mathrm{Cfu} / \mathrm{mL}$, log total mold/yeast $5.86 \mathrm{Cfu} / \mathrm{mL}$. Beyond the 12 hour-storage, both of the lolohs had higher total colony counts than the upper standard limit.
\end{abstract}

Keywords: Loloh; physicochemical and microbiological changes; shelf life; storage

\begin{abstract}
Loloh is a Balinese traditional beverage made from one or a combination of several herbal extracts. The most popular variants of loloh in Bali are loloh tibah and loloh cem-cem, which are continuously produced every day. During distribution, loloh is stored at room temperature. The study was aimed to study the physico-chemical and microbiological characteristics of loloh cem-cem and loloh tibah during storage at room temperature. This study used a purposive random sampling. The samples consisted of 14 loloh sellers in Badung-Denpasar. Type parameters that were observed during a 24 hour-storage at room temperature included $\mathrm{pH}$, total soluble solid, titratable acidity, ascorbic acid, total plate count, total yeast and mold count. During room temperature storage, the level of total plate count, total mold/yeast of loloh cem-cem and loloh tibah changed significantly. The shelf life of loloh cem-cem was only 12 hours at room temperature (28-30 oC) with the characteristics of pH 2.95, TSS $5.67^{\circ}$ Brix, vitamin C $19.35 \mathrm{mg} / 100 \mathrm{~g}$, titratable acidity $0.24 \%$, log total plate count $6.48 \mathrm{Cfu} / \mathrm{mL}$, log total $\mathrm{mold} /$ yeast $5.01 \mathrm{Cfu} / \mathrm{mL}$. The shelf life of Loloh tibah was only 12 hours at room temperature $\left(28-30{ }^{\circ} \mathrm{C}\right)$ with the characteristics of pH 3.34 , TSS $4.21^{\circ}$ Brix, Vitamin C $10.20 \mathrm{mg} / 100 \mathrm{~g}$, titratable acidity $0.13 \%$, log total plate count
\end{abstract}


6.68 Cfu/mL, log total mold/yeast $5.86 \mathrm{Cfu} / \mathrm{mL}$. Beyond the 12 hour-storage, both of the lolohs had higher total colony counts than the upper standard limit.

Keywords: Loloh; physicochemical and microbiological changes; shelf life; storage

\section{PENDAHULUAN}

Loloh merupakan salah satu minuman tradisional khas Bali yang terbuat dari satu atau campuran dari tanaman herbal. Terdapat 17 jenis minuman tradisional Bali (Yusa and Suter, 2012), 2 diantaranya telah banyak diproduksi/dipasarkan, yaitu: Ioloh cem-cem dan loloh tibah. Penamaan loloh berdasarkan jenis bahan utama yang dipergunakan. Loloh cem-cem bahan utamanya daun kecem-cem (Spondiaz pinnata (L.f) Kurz) sedangkan loloh tibah bahan utamanya buah mengkudu (Morinda citrifolia L.), dalam bahasa Bali dinamakan tibah. Loloh cem-cem terbuat dari ekstrak daun cem-cem dengan air (20\%) dihaluskan kemudian disaring, pada filtrat ditambahkan sirup gula kemudian ditambahkan serutan kelapa muda sebagai bahan pengisi, selanjutnya siap untuk dikemas dalam botol plastik. Loloh Tibah terbuat dari buah mengkudu yang diekstrak menggunakan air dan diberikan penambahan asam, terasi, gula, garam dan cabai untuk meningkatkan citarasa. Rasa khas buah mengkudu dihilangkan dengan meremas-meremas mempergunakan garam dan selanjutnya dicuci, dicampur dengan gula, asam, terasi dan cabai kemudian diekstrak dengan air dan disaring.

Di daerah Denpasar terdapat 14 produsen loloh telah memproduksi produk loloh cem-cem dan loloh tibah secara kontiyu (Pratiwi dkk., 2015). Produsen loloh memproduksi loloh dengan sederhana tanpa pasteurisasi. Produsen loloh mengolah loloh pada pagi ataupun malam hari sebelum dipasarkan. Pada tempat pemasaran, loloh sebagian besar akan disimpan pada suhu kamar dengan waktu pemasaran sampai dengan jam 18.00 WITA (Pratiwi dkk., 2015 ).

Mutu produk dianggap dalam keadaan $100 \%$ pada saat diproduksi dan akan menurun sejalan dengan lamanya penyimpanan atau distribusi (Herawati, 2006). Salah satu penentu mutu dari produk pangan adalah kandungan mikroba dari bahan pangan tersebut. Kandungan mikroba, selain mempengaruhi mutu produk pangan juga menentukan keamanan produk tersebut dikonsumsi (Herawati, 2006). Selanjutnya dikemukakan bahwa pengolahan sari buah tanpa pasteurisasi akan menurunkan kestabilan produk selama penyimpanan dan sangat memungkinkan produk menjadi tidak aman karena adanya pertumbuhan bakteri patogen dan bakteri pembusuk (Supraditareporn dan Pinthong, 2007)
Loloh cem-cem dan loloh tibah sangat diminati di daerah Denpasar karena minuman ini sangat memiliki manfaat bagi kesehatan. Nilai fungsional dari loloh berhubungan dengan senyawa aktif yang terkandung dari bahan dasarnya yaitu daun cem-cem dan buah mengkudu. Daun muda, kulit batang dan kulit akar dari tanaman cemcem mengandung saponin, flavonoid dan tanin (Gupta dkk., 2010). Ekstrak methanol dan aquades daun cemcem memiliki aktivitas sebagai antidiare (Kumar Panda dkk., 2012). Pada tanaman mengkudu, kurang lebih 160 senyawa telah diidentifikasi dari tanaman mengkudu ini, dengan komponen mikronutrien yang utama adalah senyawa-senyawa fenolik, asam-asam organik, dan alkaloid. Selanjutnya dikemukakan bahwa senyawa-senyawa fenolik telah dilaporkan mempunyai aktivitas antioksidan karena sifat-sifat redoksnya (Riyanto dan Rohman, 2007). Buah mengkudu mengandung alkaloid yang dinamakan xeronin. Semua sel yang dimasuki xeronin ini akan menjadi aktif, lebih sehat, dan terjadi perbaikan struktur maupun fungsinya (Fikri, 2015). Xeronin dibentuk oleh suatu zat yang dinamakan proxeronin dan dihasilkan ketika asam lambung yang sedang mencerna buah mengkudu mengubah proxeronin sampai menjadi xeronin (Abou dkk., 2017). Berdasarkan hal tersebut maka sangat disayangkan jika khasiat dari loloh terlupakan karena tingginya faktor resiko akibat proses penyimpanan yang tidak tepat. Selama ini, belum ada standar mengenai masa simpan dari loloh. Sebanyak $64,28 \%$ dari produsen loloh menyatakan sisa produk yang tidak habis terjual akan disimpan kembali di lemari pendingin untuk dijual kembali (Pratiwi dkk., $2015^{\mathrm{b}}$ ). Suhu penyimpanan merupakan faktor pembatas terpenting untuk menentukan masa simpan dari suatu produk pangan yang terbuat dari buah-buahan (Okudu dan Ene Obong, 2015).

Penyimpanan pada suhu kamar dan lamanya waktu distribusi loloh hingga ke konsumen dapat meningkatkan resiko kontaminasi produk loloh akibat peningkatan jumlah bakteri patogen maupun pembusuk. Berdasarkan hal tersebut, maka penelitian ini bertujuan untuk mengetahui perubahan fisiko-kimia dan mikrobiologis selama penyimpanan pada suhu kamar sehingga dapat menjadi standar acuan dalam penyimpanan loloh dalam upaya untuk meningkatkan keamanan pangan. 


\section{METODE PENELITIAN}

\section{Metode Penelitian}

Penentuan jumlah sampel berdasarkan metode purposive sampling yaitu pengambilan sampel berdasarkan tujuan tertentu. Salah satu kriteria produsen yang akan digunakan sebagai sampling adalah produsen tersebut harus secara kontinyu memproduksi loloh tibah dan cem-cem setiap hari. Berdasarkan hasil sampling di daerah Badung-Denpasar terdapat 14 produsen loloh cem-cem dan loloh tibah (Tabel 1) yang memproduksi loloh secara kontinyu dan memasarkan produk lolohnya di beberapa pasar tradisional di daerah Denpasar dan Badung. Sampel loloh cemcem dan loloh tibah yang telah dikemas dalam botol plastik Polyethylene Terephthalate (PET) diambil pada masing-masing produsen pada jam ke-0 (setelah selesai produksi), disimpan dalam coolbox dan segera dibawa ke laboratorium untuk dilakukan analisis karakteristik kimia dan mikrobiologis selama penyimpanan 24 jam pada suhu kamar $\left(28-30^{\circ} \mathrm{C}\right)$.

Pengujian terhadap $\mathrm{pH}$, TSS, kadar vitamin C, total asam, total mikroba dan total kapang/khamir dilakukan pada penyimpanan 0 jam, 6 jam, 12 jam, 18 jam dan 24 jam. Pengujian sampel loloh cem-cem dan loloh tibah meliputi pengujian terhadap pH (AOAC, 2006), total padatan terlarut (AOAC, 2006), total asam (AOAC, 2006), total vitamin C (AOAC, 2006), total mikroba (Standard Plate Count Procedure) (Fardiaz, 2004), total kapang (metode hitungan cawan) (Fardiaz, 2004). Data hasil pengamatan dianalisis dengan analisis keragaman (analysis of variance) pada taraf nyata $5 \%$ menggunakan ANOVA. Apabila terdapat perbedaan yang nyata, maka dilanjutkan dengan uji lanjut dengan uji Duncan Multiple Range Test (DMRT) (Hanafiah, 2002).

\section{Bahan}

Bahan yang digunakan dalam penelitian ini diantaranya adalah loloh cemcem dan loloh tibah, media Plate Count Agar (Oxoid), Pepton Water (Oxoid), Aquadest, Potato dextrose-agar (Oxoid), alkohol 96\%,
$\mathrm{NaOH}$ 0,1N (Merck), Kalium iodida, I2 (Merck), Amilum (Merck), Phenolpthalein (Merck).

\begin{abstract}
Alat
Alat-alat yang digunakan dalam penelitian ini diantaranya adalah : cawan petri, tabung reaksi, tabung durham, gelas ukur (Iwaki pyrex), batang bengkok, vortex (Labinco), laminar air flow cabinet $(E S L)$, inkubator (Memmert), autoclave (Hirayama), sprayer, pipet mikro (Gilson $1000 \mu \mathrm{l})$, timbangan analitik (Shimadzu ATY224), pH meter (Schott), hand refraktometer (ATAGO 0-32 ( $\left.{ }^{\mathrm{B} B r i x}\right)$ ).
\end{abstract}

\section{HASIL DAN PEMBAHASAN}

\section{Kondisi Proses Pengolahan Loloh Cem-cem dan Loloh Tibah}

Kondisi proses pengolahan loloh cem-cem dan loloh tibah tergolong masih sederhana dan terdapat beberapa kendala dalam produksi loloh antara lain: keterbatasan ketersediaan bahan baku karena selama ini bahan baku loloh yang digunakan dalam bentuk segar, sehingga jumlah produksi per hari loloh terbatas tergantung jumlah bahan baku yang tersedia. Rendahnya sanitasi produsen loloh, meliputi: a) tempat pengolahan yang tidak memiliki ruang khusus untuk mengolah loloh seluruh pedagang loloh belum memiliki ruang khusus dalam pengolahan loloh, produsen mengolah loloh di dapur ataupun di halaman rumah; b) penggunaan botol kemasan: botol kemasan yang dipergunakan untuk mengemas loloh, sebagian besar mempergunakan botol bekas dengan tujuan untuk menghemat biaya produksi ( $42,86 \%$ menggunakan botol bekas; $35,71 \%$ menggunakan botol baru, $21,43 \%$ menggunakan keduanya); c). Penggunaan air produksi: jenis air yang digunakan untuk produksi adalah air isi ulang yang dimatangkan kembali $(42,86 \%)$, air isi ulang $(42,86 \%)$, air mineral merk aqua $(7,14 \%)$, dan air dari sumber mata air (7,14\%). Belum terdapat standar baku (formula/resep) dalam pembuatan loloh yang

Tabel 1. Produsen loloh cem-cem dan tibah di wilayah Badung dan Denpasar

\begin{tabular}{ccl}
\hline Jenis loloh & Jumlah & \multicolumn{1}{c}{ Lokasi produsen } \\
\hline Loloh cem-cem & 8 buah & $\begin{array}{l}\text { Daerah Gatot Subroto, Denpasar; daerah Denpasar Timur (Jl. Subita); Pasar } \\
\text { Agung; Pasar Kreneng; Pasar Badung; Gunung Agung; Penarungan; Blah Kiuh }\end{array}$ \\
Loloh tibah & 6 buah & $\begin{array}{l}\text { Daerah Gatot Subroto, Denpasar Timur; daerah Pasar Mengwi, Badung; Pasar } \\
\text { Badung; Gunung Agung; Petang 1; Petang 2 }\end{array}$ \\
\hline
\end{tabular}

Sumber: (Pratiwi dkk., 2015ª) 
baku sehingga loloh yang dihasilkan memiliki kualitas dapat berbeda-beda terutama dari segi sensoris. Penggunaan bahan baku pembuatan loloh berdasarkan hasil perkiraan dari produsen. Belum studi yang menjadi patokan mengenai masa simpan dari loloh, 64,28\% dari produsen loloh menyatakan sisa produk yang tidak habis terjual akan disimpan kembali di lemari es untuk dijual kembali (Pratiwi dkk., 2015 ).

\section{Perubahan Karakteristik Selama Penyimpanan Loloh Cem-cem}

Hasil analisis statistik menunjukkan bahwa lama penyimpanan loloh cem-cem pada suhu kamar (28-30 $\left.{ }^{\circ} \mathrm{C}\right)$ berpengaruh nyata terhadap nilai log total mikroba dari loloh cem-cem. Hasil uji lanjut menunjukkan bahwa log total mikroba loloh cem-cem yang disimpan selama $0,6,12,18$, dan 24 jam masing-masing berbeda. Terjadi peningkatan nilai log total mikroba loloh cem-cem seiring dengan lamanya penyimpanan. Hasil analisis kimia dan mikrobiologis pada loloh cem-cem selama penyimpanan disajikan pada Tabel 2.

Berdasarkan peraturan Kepala Badan Pengawas Obat dan Makanan (BPOM) No. 12 tahun 2014 mengenai persyaratan mutu obat tradisional maka jumlah cemaran mikroba pada minuman tradisional adalah $\leq 10^{6} \mathrm{koloni} / \mathrm{mL}$ (BPOM, 2014). Nilai total mikroba pada penyimpanan jam ke-0 adalah $10^{5} \mathrm{CFU} /$ $\mathrm{mL}$, nilai total mikroba meningkat menjadi rata-rata $10^{7} \mathrm{CFU} / \mathrm{mL}$ setelah disimpan selama 18 jam sehingga dapat diasumsikan bahwa keseluruhan loloh tidak layak dikonsumsi kembali jika telah disimpan (dipasarkan) lebih dari 12 jam.

Tingginya nilai log total mikroba pada penyimpanan 0 jam dipengaruhi oleh jumlah mikroba awal pada bahan baku (daun cem-cem, air, kelapa parut) serta rendahnya sanitasi selama proses pengolahan loloh. Loloh merupakan produk minuman ready to serve yang harus melalui penanganan higienis selama pengolahan, sehingga tidak tercemar oleh mikroba kontaminan. Mikroba kontaminasi yang paling sering menjadi penyebab kerusakan sari buah berasal dari permukaan tanaman dan buah (Okudu dan Ene Obong, 2015). Bahan pangan dapat tercemar mikroba sebelum pengolahan (pencemaran primer) atau selanjutnya setelah pengolahan (pencemaran sekunder), kebiasaan pribadi dari para pekerja dalam mengelola produk pangan dapat merupakan sumber yang penting dari pencemaran sekunder (Buckle dkk., 1987). Penurunan jumlah total mikroba sangat berkaitan dengan proses pasteurisasi dan penangannya yang tepat (Okudu dan Ene Obong, 2015).

Peningkatan jumlah mikroba pada loloh cem-cem selama penyimpanan 24 jam diduga berhubungan dengan kandungan nutrisi, seperti kandungan sukrosa dari sirup gula. Selama tersedianya nutrisi, mikroba akan tumbuh dan berkembang sehingga mengakibatkan kerusakan pada loloh cem-cem. Pada tahap awal penyimpanan, kandungan gula sari buah C.lepidota akan meningkatkan pertumbuhan mikroba karena gula merupakan sumber nutrisi bagi mikroba untuk melakukan metabolisme. Jumlah total mikroba mengalami penurunan pada minggu kedua dan ketiga karena mikroba mengalami akibat kekurangan nutrisi (Okudu dan Ene Obong, 2015). Sari buah merupakan subrat yang sesuai bagi pertumbuhan mikroba terutama bakteri dan khamir, karena bersifat mampu bertahan pada suhu tinggi dan tumbuh pada $\mathrm{pH}$ yang rendah. Mikroba ini dapat menurunkan kualitas sari buah dengan merendahkan beberapa senyawa (karbohidrat, protein dan vitamin), menghasilkan bau yang tidak diinginkan (off flavor), perubahan warna, penurunan $\mathrm{pH}$ dan tekstur. Selanjutnya dikemukakan kembali bahwa pada nilai TSS dibawah $11^{\circ}$ Brix, produk minuman sari buah menjadi rentan terhadap kontaminasi mikroba (Batra, Sharma, dan Agarwal, 2018)congestive heart failure (CHF

Tabel 2. Karakteristik fisiko-kimiawi dan mikrobiologis loloh cem-cem dan perubahannya selama penyimpanan

\begin{tabular}{|c|c|c|c|c|c|}
\hline \multirow{2}{*}{ Parameter } & \multicolumn{5}{|c|}{ Masa penyimpanan (jam) } \\
\hline & 0 & 6 & 12 & 18 & 24 \\
\hline $\mathrm{pH}$ & $3,04 \pm 0,26^{a}$ & $3,00 \pm 0,27 \mathrm{a}$ & $2,95 \pm 0,30^{a}$ & $2,85 \pm 0,33^{a}$ & $2,76 \pm 0,36^{a}$ \\
\hline Total asam (\%) & $0,24 \pm 0,62^{a}$ & $0,24 \pm 0,48^{a}$ & $0,24 \pm 0,53^{a}$ & $0,24 \pm 0,72^{a}$ & $0,25 \pm 0,46^{a}$ \\
\hline TSS ( ${ }^{\circ}$ Brix) & $5,76 \pm 2,44^{a}$ & $5,58 \pm 2,55^{a}$ & $5,67 \pm 2,45^{a}$ & $5,75 \pm 2,39 a$ & $5,58 \pm 2,30^{a}$ \\
\hline Vitamin C (mg/100mL) & $21,99 \pm 0,97^{a}$ & $20,89 \pm 0,89$ a & $19,35 \pm 1,05^{a}$ & $17,59 \pm 0,79$ a & $16,49 \pm 0,65$ \\
\hline Log total mikroba (CFU/mL) & $5,56 \pm 0,47^{a}$ & $6,11 \pm 0,76^{a b}$ & $6,48 \pm 0,32^{\mathrm{b}}$ & $7,20 \pm 0,42^{c}$ & $7,90 \pm 0,53^{d}$ \\
\hline Log total kapang (CFU/mL) & $3,98 \pm 0,78 \mathrm{a}$ & $4,59 \pm 1,05^{a b}$ & $5,01 \pm 0,59^{a b}$ & $5,54 \pm 0,82^{b}$ & $6,21 \pm 1,06^{c}$ \\
\hline
\end{tabular}

Keterangan: Angka-angka pada baris yang sama diikuti superscript yang berbeda $(a, b, c)$ menunjukkan pengaruh yang berbeda nyata $(p<0,05)$, nilai rata-rata $\pm S D(n=16)$. 
Hasil analisis statistik menunjukkan bahwa lama penyimpanan berpengaruh nyata terhadap nilai log total kapang dari loloh cem-cem. Hasil uji lanjut menunjukkan bahwa log total kapang loloh cem-cem yang disimpan selama 0 jam dan 6 jam berbeda nyata, 6 jam dan 12 jam tidak berbeda nyata, 12, 18, dan 24 jam masingmasing berbeda. Terjadi peningkatan nilai log total mikroba loloh cem-cem seiring dengan lamanya masa simpan.

Peningkatan total mikroba dan total kapang/khamir selama disimpan berhubungan dengan suhu kamar penyimpanan. Hal ini dikarenakan suhu kamar (28-30 $\left.{ }^{\circ} \mathrm{C}\right)$ merupakan suhu optimum bagi pertumbuhan mikroba. Berdasarkan suhu optimumnya yaitu antara 25 ${ }^{\circ} \mathrm{C}-45{ }^{\circ} \mathrm{C}$, kebanyakan bakteri mesofilik mempunyai kemampuan memperbanyak diri dengan cepat. Sebagian besar kapang adalah mesofilik yang memerlukan waktu pertumbuhan dari satu sel menjadi dua sel selama 20 menit pada suhu optimum pertumbuhannya yaitu 25-30 ${ }^{\circ} \mathrm{C}$ atau suhu kamar. Peningkatan total mikroba dan total kapang/khamir diduga berhubungan dengan $\mathrm{pH}$ minimum yang memungkinkan bagi pertumbuhan bakteri. $\mathrm{pH}$ minimum bagi pertumbuhan bakteri asam laktat adalah $(\mathrm{pH} 2,9-3,5)$, bakteri asam asetat $(\mathrm{pH}$ $3,0-4,5)$, dan bakteri enterik ( $\mathrm{pH} 3,0-4,5)$ yang lebih tinggi dari pada $\mathrm{pH}$ untuk pertumbuhan kapang dan khamir Aneja, dkk., 2014). Spesies bakteri yang dilaporkan terdapat pada minuman sari buah ( $\mathrm{pH}<$ $4,5)$ yaitu genus Bacillus, Clostridium, Lactobacillus, Leuconostoc dan Bakteri asetogenik (Batra, Sharma dan Agarwal, 2018)congestive heart failure (CHF.

Derajat keasaman $(\mathrm{pH})$ mengalami penurunan selama penyimpanan, walaupun tidak signifikan $(p>0,05)$. Tingkat penurunan $\mathrm{pH}$ pada loloh tidak signifikan karena proses penyimpanan berlangsung selama 24 jam. Rendahnya pH dari loloh cem-cem berhubungan dengan kandungan bahan baku loloh yaitu daun cem-cem. Daun cem-cem secara tradisional terkenal memiliki citarasa yang asam sehingga selain dijadikan bahan baku loloh juga seringkali dimanfaatkan sebagai penghilang rasa amis pada olahan ikan.

Identifikasi terhadap senyawa pembentuk flavor pada serbuk instan daun cem-cem menyatakan bahwa terdapat 17 komponen pembentuk flavor, 6 komponen diantaranya merupakan fraksi etil asetat yaitu : 2,5 dimethyl 2- hexane, Acetic Acid Isobuthyl Ester, Ethyl 2-butenoate, Myristyl chloride, Palmitic acid methyl ester, Methyl-9-octadecenoate (Wrasiati, Antara dan Wartini, 2014). Terdapatnya fraksi etil asetat sebagai komponen pembentuk flavor diduga menjadi sumber rasa asam pada daun cem-cem. Selain itu, peningkatan keasaman produk selama penyimpanan suhu kamar diduga berhubungan dengan kemampuan mikroba memanfaatkan karbohidrat dalam jumlah yang lebih besar jika dibandingkan penyimpanan pada suhu dingin (Ashaye, Taiwo dan Adegoke, 2006).

Terjadi penurunan kadar Vitamin C selama penyimpanan 24 jam pada suhu ruang akan tetapi tingkat penurunan kadar vitamin $\mathrm{C}$ tidak signifikan $(p>0,05)$. Terjadinya penurunan kadar vitamin $\mathrm{C}$ dapat dipengaruhi oleh beberapa hal salah satunya adalah jenis botol kemasan. Kemasan PET merupakan botol plastik transparan dengan permeabilititas tinggi sehingga tidak dapat melindungi isi terutama yang mengandung bahan mudah teroksidasi seperti Vitamin C. Kemasan minuman sari buah harus dapat meminimalkan terjadinya degradasi asam askorbat (Gonzalez dkk., 2007). Penurunan vitamin C dapat terjadi karena oksidasi dan termal degradasi asam askorbat menjadi asam dehidro askorbat (Nkechi, Tamuno dan Onyedikachi, 2015). Pada pembuatan jus buah dan sayuran segar, kandungan vitamin $\mathrm{C}$ sensitif terhadap panas, cahaya dan oksigen (Kaleem dkk., 2016).

\section{Perubahan Karakteristik Selama Penyimpanan Loloh Tibah}

Hasil analisis statistik menunjukkan bahwa lama penyimpanan loloh tibah pada suhu kamar $\left(28-30^{\circ} \mathrm{C}\right)$ memberikan pengaruh nyata terhadap nilai log total mikroba. Hasil uji lanjut menunjukkan bahwa log total mikroba loloh tibah yang disimpan selama 0, 6, 12, 18, dan 24 jam masing-masing berbeda. Hasil analisis kimia dan mikrobiologis pada loloh tibah selama penyimpanan disajikan pada Tabel 3.

Terjadi penurunan kadar Vitamin $\mathrm{C}$ dari 11,33 $\mathrm{mg} / 100 \mathrm{~mL}$ (penyimpanan jam ke-0) menjadi 9,89 $\mathrm{mg} / 100 \mathrm{~mL}$ (penyimpanan jam ke-24). Pemilihan bahan kemasan yang sesuai merupakan salah satu hal yang perlu diperhatikan dalam industri makanan dan minuman karena dapat mempengaruhi kualitas dan nilai nutrisi selama masa penyimpanan. Degradasi warna dan nutrisi dapat terjadi akibat dari transmisi oksigen yang disebabkan oleh permeabilitas kemasan yang tinggi (Gonzalez dkk., 2007).

Terjadi peningkatkan total mikroba selama penyimpanan loloh tibah, nilai rata-rata total mikroba pada penyimpanan 0 jam yaitu $10^{6} \mathrm{Cfu} / \mathrm{mL}$ (0 jam) meningkat menjadi rata-rata $10^{7} \mathrm{Cfu} / \mathrm{mL}$ setelah penyimpanan 18 jam. Loloh tibah memiliki masa simpan maksimal 12 jam pada suhu kamar, setelah periode tersebut, loloh tibah tidak layak lagi dikonsumsi karena tidak memenuhi persyaratan mutu obat tradisional yaitu jumlah cemaran mikroba pada minuman tradisional adalah $\leq 10^{6}$ koloni/ $\mathrm{mL}$. Peningkatan total mikroba dari masa simpan 0 jam sampai dengan 24 jam tidak setinggi peningkatkan total mikroba pada produk loloh 
Tabel 3. Karakteristik fisiko-kimiawi dan mikrobiologis loloh tibah dan perubahannya selama penyimpanan

\begin{tabular}{lccccc}
\hline \multirow{2}{*}{ Parameter } & \multicolumn{4}{c}{ Masa penyimpanan (jam) } \\
\cline { 2 - 5 } & 0 & 6 & 12 & 24 \\
\hline pH & $3,56 \pm 0,47^{\mathrm{a}}$ & $3,54 \pm 0,43^{\mathrm{a}}$ & $3,34 \pm 0,42^{\mathrm{a}}$ & $3,30 \pm 0,41^{\mathrm{a}}$ & $3,23 \pm 0,39^{\mathrm{a}}$ \\
Total asam (\%) & $0,12 \pm 0,74^{\mathrm{a}}$ & $0,12 \pm 0,52^{\mathrm{a}}$ & $0,13 \pm 0,86^{\mathrm{a}}$ & $0,13 \pm 0,57^{\mathrm{a}}$ & $0,14 \pm 0,75^{\mathrm{a}}$ \\
TSS ('Brix) & $4,18 \pm 1,59^{\mathrm{a}}$ & $4,14 \pm 1,65^{\mathrm{a}}$ & $4,21 \pm 1,52^{\mathrm{a}}$ & $4,21 \pm 1,52^{\mathrm{a}}$ & $4,21 \pm 1,52^{\mathrm{a}}$ \\
Vitamin C (mg/100mL) & $11,33 \pm 0,93^{\mathrm{a}}$ & $11,11 \pm 0,75^{\mathrm{a}}$ & $10,20 \pm 0,68^{\mathrm{a}}$ & $10,09 \pm 0,53^{\mathrm{a}}$ & $9,89 \pm 0,67^{\mathrm{a}}$ \\
Log total mikroba (CFU/mL) & $6,00 \pm 0,52^{\mathrm{a}}$ & $6,29 \pm 0,58^{\mathrm{ab}}$ & $6,68 \pm 0,43^{\mathrm{bc}}$ & $7,16 \pm 0,51^{\mathrm{bc}}$ & $7,56 \pm 0,34^{\mathrm{b}}$ \\
Log total kapang (CFU/mL) & $4,90 \pm 0,31^{\mathrm{a}}$ & $5,67 \pm 0,59^{\mathrm{b}}$ & $5,86 \pm 0,54^{\mathrm{b}}$ & $6,65 \pm 0,76^{\mathrm{c}}$ & $6,46 \pm 0,86^{\mathrm{c}}$ \\
\hline
\end{tabular}

Keterangan: Angka-angka pada baris yang sama diikuti superscript yang berbeda $(a, b, c)$ menunjukkan pengaruh yang berbeda nyata $(p<0,05)$, nilai rata-rata $\pm \operatorname{SD}(\mathrm{n}=12)$.

cem-cem. Ekstrak buah mengkudu yang menggunakan etanol sebagai larutan pengekstrak dapat menghambat pertumbuhan Escherichia coli, Salmonella typhi dan Bacillus cereus dengan diameter penghambatan ekstrak etanol mengkudu tanpa pengenceran terhadap $E$. coli sampai dengan $25 \mathrm{~mm}$, S. typhi sampai dengan $20,90 \mathrm{~mm}$ dan $B$. cereus sampai dengan $25 \mathrm{~mm}$ (Antara, Prabanca dan Ekawati, 2014). (Trisnawati, Widpradnyadewi dan Sugitha, 2016) menyatakan bahwa ekstrak daun cemcem mampu menghambat pertumbuhan Escherichia coli ATCC 8739 dengan diameter penghambatan tertinggi pada konsentrasi $40 \%$ yaitu sebesar $4,62 \mathrm{~mm}$.

Proses penggaraman yang dilakukan pada saat mengolah loloh tibah juga merupakan salah satu faktor yang menyebabkan nilai peningkatan total mikroba loloh tibah tidak setinggi loloh cem-cem. Pemberian garam diduga dapat meningkatkan aktivitas antimikroba dari ekstrak buah mengkudu sehingga mempengaruhi jumlah peningkatan total mikroba dari loloh tibah. Penelitian yang dilakukan (Ardiansyah, Nuarida dan Andarwulan, 2003), menunjukkan bahwa larutan garam satu persen merupakan konsentrasi yang dapat meningkatkan aktivitas antimikroba ekstrak daun bluntas terhadap B. cereus (spora) dan B. subtilis (sel vegetatif dan spora). Mekanisme garam didalam pengawetan bahan pangan didasari karena kemampuan garam untuk menimbulkan terjadinya tekanan osmotik tinggi sehingga menyebabkan plasmolisis sel mikroba, terjadinya dehidrasi makanan dan mikroba karena menurukan aW bahan pangan, menghasilkan ion klorida yang berbahaya bagi mikroba dan mengurangi kelarutan oksigen sehingga sel peka terhadap $\mathrm{CO}_{2}$ (Rawat, 2015).

Selain itu, penambahan asam jawa pada pembuatan loloh tibah dapat berfungsi sebagai senyawa antimikroba, asam akan meningkatkan keawetan dari bahan pangan. Asam (Tamarinds indica L.) memiliki kemampuan sebagai antimikroba, antifungi dan antiseptik. Ekstrak ethanol buah asam (50\%) memiliki aktivitas antimikroba yang dapat mencegah pertumbuhan 10 strains bakteri (7 bakteri gram positif dan 3 bakteri gram negatif) dan 7 jenis kapang penyebab kerusakan makanan (Gupta, Prakash dan Gupta, 2014). Selain itu, penambahan asam jawa berfungsi untuk menurunkan $\mathrm{pH}$ dari ekstrak mengkudu. pH loloh tibah berada pada kisaran 3,5-3,0. Kemampuan ekstrak sebagai bahan pengawet lebih aktif pada $\mathrm{pH}$ rendah, karena berhubungan dengan bentuk tak terdisosiasi (Ardiansyah, Nuarida dan Andarwulan, 2003). Penambahan asam dan garam pada pembuatan loloh tibah secara tidak langsung dapat menurunkan jumlah mikroba dan mengurangi laju pertumbuhan mikroba pada loloh tibah selama penyimpanan.

Hasil analisis statistik menunjukkan bahwa lama penyimpanan loloh tibah memberikan pengaruh nyata terhadap nilai log total kapang. Hasil uji lanjut menunjukkan bahwa log total kapang/khamir loloh tibah yang disimpan selama 0,6 , dan 12 jam mengalami peningkatan. Setelah penyimpanan 24 jam, terjadi penurunan log total kapang/khamir yang tidak berbeda dengan lama penyimpanan 18 jam.

Tingginya kandungan total kapang/khamir dari loloh tibah diduga karena rendahnya sanitasi dan higienis dari produsen loloh. Selain itu dapat juga diakibatkan kontaminasi dari udara pada saat proses pengemasan, wadah kemasan yang kurang steril dan kontaminasi dari bahan baku yang dipergunakan dalam mengolah loloh. Terjadi peningkatan jumlah total kapang/khamir sampai dengan penyimpanan 18 jam, setelah penyimpanan mencapai 24 jam, total kapang/khamir sari loloh tibah cenderung mengalami penurunan. Terjadi penurunan total kapang/khamir disebabkan karena telah terjadi fase pertumbuhan lambat, dimana jumlah kandungan nutrisi semakin rendah dan terjadinya persaingan nutrisi dengan mikroba lainnya sehingga 
mengakibatkan kapang/khamir menuju fase kematian dan mengakibatkan total kapang/khamir berkurang (Fardiaz, 1992).

\section{KESIMPULAN}

Penyimpanan loloh cem-cem pada suhu kamar $\left(28-30^{\circ} \mathrm{C}\right.$ ) selama 24 jam memberikan pengaruh nyata terhadap total mikroba, total kapang/khamir. Loloh cem-cem memiliki masa simpan maksimal 12 jam pada suhu kamar $\left(28-30^{\circ} \mathrm{C}\right)$ dengan karakteristik loloh cemcem yaitu $\mathrm{pH} 2,95$, TSS 5,67 OBrix, Total Vitamin C $19,35 \mathrm{mg} / 100 \mathrm{~g}$, total asam $0,24 \%$, total mikroba 6,48 $\log \mathrm{Cfu} / \mathrm{mL}$, total kapang 5,01 log Cfu/mL. Penyimpanan loloh tibah pada suhu kamar $\left(28-30^{\circ} \mathrm{C}\right)$ selama 24 jam memberikan pengaruh nyata terhadap total mikroba dan total kapang/khamir. Loloh tibah memiliki masa simpan maksimal 12 jam pada suhu kamar $\left(28-30^{\circ} \mathrm{C}\right)$ dengan

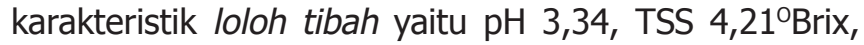
Total Vitamin C 10,20 mg/100g, total asam 0,13\%, total mikroba 6,68 log Cfu/mL, total kapang 5,86 log Cfu/mL. Setelah periode tersebut, loloh cem-cem dan loloh tibah tidak layak lagi dikonsumsi.

\section{UCAPAN TERIMA KASIH}

Penulis mengucapkan terimakasih semua pihak yang telah membantu kelancaran penelitian dan khususnya terima kasih kepada LPPM-Universitas Udayana yang telah memfasilitasi dan memberikan dukungan dana penelitian melalui Program Hibah Unggulan Udayana Tahun Anggaran 2015 dengan nomor kontrak 246-341/UN14.2/PNL.01.03.00/2015 tertanggal 21 April 2015.

\section{KONFLIK KEPENTINGAN}

Pada penelitian serta publikasi ini, tidak ada conflict of interest dari semua pihak.

\section{DAFTAR PUSTAKA}

Abou, R. A., Y. Darwis, I.M. Abdulbaqi, A.A. Khan, L.Vuanghao, M.H. Laghari (2017) 'Morinda citrifolia ( Noni ): A comprehensive review on its industrial uses , pharmacological activities, and clinical trials', Arabian Journal of Chemistry. King Saud University, 10(5), pp. 691-707. doi: 10.1016/j.arabjc.2015.06.018.

AOAC (2006). Official Method of Analysis. Association of Official Analytical Chemist (AOAC). Published by the Association of Official Analytical Chemist. Washington DC, USA
Aneja, K. R., R. Dhiman, N. Kumar A., V. Kumar, M. Kaur (2014) 'Microbes associated with freshly prepared juices of citrus and carrots', International Journal of Food Science, 2014. doi: 10.1155/2014/408085.

Antara, N. S., Prabanca, V. G. dan Ekawati, I. G. A. (2014) 'Aktivitas Antimikroba Ekstrak Bubuk Buah Mengkudu ( Morinda citrifolia L .) terhadap Pertumbuhan Bakteri Patogen', Media Ilmiah Teknologi Pangan, 1(1), pp. 1-9.

Ardiansyah, Nuarida, L. dan Andarwulan, N. (2003) 'Aktivitas Antimikroba Daun Beluntas (Plucea indica L.) dan Stabilitas Aktivitasnya pada Berbagai Konsentrasi Garam dan Tingkat $\mathrm{pH}^{\prime}$, Jurnal Teknologi dan Industri Pangan, 14(2), pp. 90-97.

Ashaye, O. A., Taiwo, O. O. dan Adegoke, G. O. (2006) 'Effect of local preservative (Aframomum danielli) on the chemical and sensory properties of stored warakanshi', African Journal of Agricultural Research, 1(August), pp. 10-16.

Badan Pengawas Obat dan Makanan (2014) Persyaratan Mutu Obat Tradisional.

Batra, N. G., Sharma, A. dan Agarwal, N. (2018) 'Evaluation of microbiological criteria and quality of packed fruit juices', International Food Research Journal, 25(2), pp. 459-461.

Bukcle, K.A., R.A. Edwards, G.H. Fleet, dan M. Wooton. (1987). Ilmu Pangan. Penerbit

Universitas Indonesia (UI-Press) . Jakarta.

Fardiaz, S. (1992). Mikrobiologi Pangan 1. Gramedia Pustaka Utama, Jakarta.

Fardiaz, S. (2004). Analisa Mikrobiologi Pangan. Raja Grafindo Persada, Jakarta

Fikri, K. (2015) 'Potensi Buah Mengkudu ( Morinda Citrifolia L .) Sebagai Anti Radang Pada Luka Gores Mencit Jantan ( Morinda Citrifolia L . Fruit Potency As Anti Inflamatory In Male Mice Scratch )', Journal Unej Saintifika, 17(1), Pp. 14-19.

Gonzalez, F. B. Et Al. (2007) 'Effect Of Packaging Materials On Color, Vitamin C And Sensory Quality Of Refrigerated Mandarin Juice', Journal Of Food Quality, 31(2008), Pp. 596-611.

Gupta, C., Prakash, D. dan Gupta, S. (2014) 'Studies on the antimicrobial activity of tamarind (Tamarindus indica) and its potential as food bio-preservative', International Food Research Journal, 21(6), pp. 2437-2441.

Gupta, V. K. et al. (2010) 'Antimicrobial activity of Spondias pinnata resin', Journal of Medicinal Plants Research, 4(16), pp. 1656-1661. doi: 10.5897/JMPR10.182.

Hanafiah, K.A. (2002). Rancangan Percobaan : Teori dan Aplikasi. PT. Raja Grafindo Permata, Jakarta.

Herawati, H. (2006). Penentuan Umur Simpan pada Produk Pangan', Balai Pengkajian Teknologi Pertanian Jawa Tengah, 34(1974), P. 427. 
Kaleem, A. Et Al. (2016) 'Investigation Of The Effect Of Temperatute On Vitamin C In Fresh And Packed Fruit Juices', Fuuast Journal Biology, 6(1), Pp. 117-120.

Kumar Panda, S. et al. (2012) 'Anti-diarrheal activities of medicinal plants of Similipal Biosphere Re- serve, Odisha, India', Int. J. Med. Arom. Plants, 2(1), pp. 2249-4340. Available at: http://www.openaccessscience.com.

Nkechi, E., Tamuno, J. dan Onyedikachi, E. C. (2015) 'Effect of Packaging Materials, Storage Conditions on the Vitamin C and pH Value of Cashew Apple ( Anacardium occidentale L .) Juice', Journal of Food and Nutrition Sciences, 3(4), pp. 160-165. doi: $10.11648 / j . j f n s .20150304 .14$.

Okudu, H. O. dan Ene Obong, H. (2015) 'Evaluation of the effect of storage time and temperature on some physicochemical properties of juice and jam developed from two varieties of monkey kola (Cola parchycarpa, Cola lepidota)', African Journal of Food Science and Technology, 6(7), pp. 21415455. doi: 10.14303/ajfst.2015.063.

Pratiwi, IDPK., IK. Suter, A.Widpradnyadewi, dan AAS Wiadnyani. (2015) 'SEMINAR NASIONAL SAINS', in Prevalensi cemaran mikrobiologis dan logam berat $(\mathrm{Pb}, \mathrm{Cd})$ pada minuman tradisional (Ioloh) di daerah Denpasar dan Badung. Denpasar: Universitas Udayana, pp. 863-870.

Pratiwi, IDPK., IK. Suter, A.Widpradnyadewi, dan AAS Wiadnyani. (2015) 'Prevalensi Cemaran Mikrobiologis Dan Logam Berat Pada Minuman Tradisional ( Loloh ) Dalam Upaya Peningkatan Mutu Pangan' Laporan Penelitian Hibah Unggulan. Universitas Udayana.
Rawat, S. (2015) 'Food Spoilage: Microorganisms and their prevention', Pelagia Research Library Asian Journal of Plant Science and Research, 5(4), pp. 47-56. Available at: www.pelagiaresearchlibrary. com.

Riyanto dan Rohman (2007) 'Isolasi skopoletin dari buah mengkudu (Morinda citrifolia L.) dan Uji Aktvitas Antioksidannya. Agritech, 27(3), pp. 107-111.

Supraditareporn dan Pinthong (2007) 'Physical, Chemical and Microbiological Changes during Storage of Orange Juices CV . Sai Nam Pung and CV . Khieo Waan in', pp. 726-730.

Trisnawati, N. R., Widpradnyadewi, P. A. S. dan Sugitha, I. M. (2016) 'Daya Hambat Ekstrak Daun Cemcem (Spondias Pinnata (L.F) Kurz.) Terhadap Pertumbuhan Escherichia Coli Atcc 8739 Secara In Vitro', Journal Ilmu dan Teknologi Pangan, 5(2), pp. 119-129.

Wrasiati, L. P., Antara, I. N. S. dan Wartini, N. M. (2014) 'Characteristics of Cemcem (Spondiaz pinnata L.F. Kurz) Instant Powder'.

Yusa, N. M. dan Suter, I. K. (2012) Kajian Pangan Tradisional Bali dalam Rangka Pengmbangannya Menjadi Produk Unggulan di Kabupaten Gianyar. Laporan Penelitian Hibah Unggulan Penelitian. Fakultas Teknologi Pertanian. Universitas Udayana, Denpasar. 